Article

\title{
Clients' Faith Experiences as an Opportunity or a Challenge for Psychotherapy: A Qualitative Analysis of Clinical Records
}

\author{
Aida Hougaard Andersen ${ }^{1, *}{ }^{(\mathbb{C}}$, Dorte Toudal Viftrup ${ }^{2} \mathbb{O}$, Heidi Frølund Pedersen ${ }^{3}$ and \\ Kirsten K. Roessler ${ }^{1}$ (D) \\ 1 Department of Psychology, University of Southern Denmark, 5230 Odense M, Denmark; \\ kroessler@health.sdu.dk \\ 2 Research Unit of General Practice, University of Southern Denmark, 5000 Odense C, Denmark; \\ dviftrup@health.sdu.dk \\ 3 Research Clinic for Functional Disorders and Psychosomatics, Aarhus University Hospital, \\ 8000 Aarhus C, Denmark; heidifrolund@au.dk \\ * Correspondence: ahandersen@health.sdu.dk
}

Received: 25 July 2020; Accepted: 27 September 2020; Published: 1 October 2020

\begin{abstract}
Faith experiences constitute important sources of meaning but also a risk of religious struggles. However, studies exploring the faith experiences of clients in relation to psychological functioning in psychotherapy are needed, especially in secularized countries. This study investigated how clients described faith experiences when addressed in psychotherapy, how they experienced faith in relation to coping, and how the experiences were integrated into the psychotherapy. Written records of 33 clients from a psychological clinic with outpatient care in Denmark were analyzed using interpretative phenomenological analysis. The most prevalent diagnoses among the clients were stress, depression, anxiety, and life crises. The clients reported that spiritual and religious beliefs functioned as sources of meaning and constituted either a strength, a challenge, or a combination of both. The psychosocial life and coping strategies of the clients were interwoven with faith experiences. A psychological, resource-focused approach in relation to the clients' religious challenges seemed to help them toward a more flexible and resource-oriented faith. Assessing faith experiences as sources of meaning in a therapeutic approach focusing on the client's resources may increase both the psychological functioning of clients and the therapists' understanding of clients' lifeworlds.
\end{abstract}

Keywords: clinical psychology of religion; religious coping; spirituality; faith; interpretative phenomenological analysis; psychotherapy

\section{Introduction}

Patient-centeredness became pivotal in modern healthcare (Balint 1969; Thompson 2007) due to the introduction of the bio-psycho-social model (Engel 1977). Integrating psychosocial aspects in a healthcare context represented a great step forward. However, the bio-psycho-social model still lacked dimensions of importance for the patient. Therefore, a growing body of researchers recommended including an existential, or spiritual, dimension as well (Sulmasy 2002; Dezutter et al. 2016; Koenig et al. 2012; Pargament 2007; APA 2013; Dyer 2011). In this article, faith is defined as the client's belief in anything transcendent to which he or she can adhere to (Moestrup and Hvidt 2016) and covers the practice of both spirituality and religiosity. As such, faith was found to be a significant source of meaning that could be used to elicit the experience of meaningfulness in life and is positively related to psychological health (Schnell 2011; Pedersen et al. 2018; Van der Heyden et al. 2015). Moreover, faith is a significant factor that constitutes potential positive coping strategies for the individual (Mueller et al. 
2001; Stewart et al. 2013; Koenig et al. 2020). Though spirituality and religiosity often serve as positive coping resources in times of crisis, the opposite, defined as a religious struggle or negative religious coping, is likewise well documented and associated with stress, lower self-esteem, and higher levels of depression and anxiety (Fitchett et al. 2004; Abu-Raiya et al. 2015; Abu-Raiya et al. 2016; Ano and Vasconcelles 2005; Exline 2013). Even in a so-called secular society, such as Denmark, with a general decline in religious belief and practice, existential and religious thoughts seem to intensify in times of crisis (Larsen et al. 2017; Ausker et al. 2008), and religious struggles, such as thoughts about illness as a punishment from God, correlated with a lower quality of life (Pedersen et al. 2013). Moreover, there seem to be a substantial group of people in secularized countries adhering to religion and spirituality in their life in general (Viftrup et al. 2017; Hvidt et al. 2017; La Cour 2008); studies are needed to explore how clients experience their faith in times of crisis when living in a secular country with an integrated religiosity or spirituality.

Although research has shown that faith is a legitimate human expression that influences health, healthcare personnel seemed reluctant to approach these needs (Dezutter et al. 2016; Assing Hvidt et al. 2016; Andersen et al. 2019). This may have been due to a lack of knowledge and/or training, as well as an apprehension regarding imposing their own meaning system on the patients (Andersen et al. 2020; Mueller et al. 2001; Best et al. 2016). For psychologists, their hesitant approach might also partly be based historically on Sigmund Freud's view on religion as an immature projection of the need for defense and protection (Freud 1989), although other psychoanalysts argued for an understanding of religion as a fundamental dimension of human life (Rizzuto 1979; Fromm 1983). The hesitation might also possibly stem from a lack of personal interest since psychologists overall are less religiously oriented than spiritually oriented compared with the general population (Delaney et al. 2007; Reme 2014; Smith and Orlinsky 2004).

How to integrate and use a client's spirituality or religion in psychotherapy has evolved in theory and research has been done from different psychological perspectives (Pargament 2007; Aten et al. 2012). From the general coping theory (Lazarus and Folkman 1984), Pargament developed an empirically based theoretical understanding of how people use what they hold as "sacred" in life to cope with distress (Pargament 1997, 2007; Pargament et al. 2017). This dynamic theory of religious coping emphasized how religion and spirituality constitute different coping methods with different functions for the individual, including active, passive, and interactive strategies, as well as emotional or problem-focused approaches (Pargament et al. 2013). The importance of psychologically addressing religious struggles was further emphasized based on psychologists' professional competences and ethical responsibility (Gonsiorek et al. 2009). Addressing existential and religious issues in psychotherapy indicated a possible benefit for mental health (Viftrup et al. 2016; Stålsett et al. 2012; Gebler and Maercker 2014). However, the therapeutic approaches and methods used were often specific in ways that challenged their generalizability to the methods applied by psychologists without this specific existential or theological knowledge and training. Accordingly, some psychotherapists also reported significant challenges regarding addressing faith experiences in psychotherapy (Tomcsányi et al. 2017), and spiritual and religious topics seemed to be underrepresented in training and education (Hofmann and Walach 2011). Consequently, there appears to be a need for exploring how to integrate the clients' faith experiences as a part of already existing psychological practices and psychotherapeutic approaches.

The aim of the current study was to explore the role of the client's faith experiences in individual therapy as stated in the records and to discuss the possible implications for clinical practice with the use of psychological theories on psychological functioning and faith.

Research questions:

1. How do clients with a spiritual or religious orientation describe their faith experiences when asked in psychotherapy?

2. What do the resources and challenges of the faith imply for the clients' psychological functioning?

3. How can psychologists use this knowledge in clinical practice and psychotherapy? 


\section{Materials and Methods}

\subsection{Setting}

This study took place in a psychological clinic founded by a Christian diaconal organization (Agape) that involved both counseling and treating functions. The treating function was covered by the psychological clinic where licensed psychologists provided psychotherapy and supervision. Clients were either self-referred or referred to the clinic by a family physician for different reasons, such as anxiety, depression, stress, relational challenges, or traumatic experiences. All clients were ethnic Danes. Although these clients were citizens in a secular country, most of them had a Lutheran or charismatic Christian value-based background or religious orientation, which made the group of clients appropriate for our study.

The two therapists in the psychological clinic were authorized psychologists with a client-centered approach, meaning there was a primacy to the alliance and contract with the client, and they were primarily educated in cognitive behavioral therapy. The approach used to address faith experiences was from the perspective of the clinical psychology of religion. This perspective focuses not on the truth value of the clients' meaning system but on the psychological and social function of the meaning system (Austad and Follesø 2003). During the closing session, the psychologists asked the client to orally evaluate the importance of the integration of faith in psychotherapy and recorded the clients' descriptions.

\subsection{Sample and Data Collection}

Clients aged above 18 years receiving individual therapy, who gave written informed consent, were consecutively included in the study from early 2014 until early 2015. Data were registered in journals for each client and eventually gathered in a shared, pseudo-anonymized database. The psychologists were instructed to ask the clients what they experienced as being meaningful in life, including whether they believed in anything transcendent. Furthermore, they systematically stated in their journals whether faith issues were a part of the psychotherapy and how they have approached and intervened according to these themes. Consequently, our material contains the psychologists' records of both the clients' expressions as stated during the psychotherapy and the psychologists' professional reflections regarding faith experiences in psychotherapy.

\subsection{Ethics}

The Danish Data Protection Agency approved the project J.nr. 2015-41-4469. The University of Southern Denmark (SDU) was in charge of processing the personal data in connection with the project, which has been included in SDU's internal record of processing activities under file number [10.048], cf. GDPR Article 30.

\subsection{Analysis}

The analysis was conducted in line with interpretative phenomenological analysis (IPA) (Smith et al. 2009). As an interpretative method, IPA presupposes that the data is generated in a certain context and must be understood as such. Our research data is generated as a part of psychotherapy, and this context is fundamental when understanding and analyzing the data. IPA is concerned with understanding each case to make sense of the individual's experiences and recommends an open approach to data analysis, with an attempt to bracket one's own presuppositions. As is also recommended for the discussion section of an IPA study (Smith et al. 2009, p. 112), we engaged in a dialogue between our findings and selected extended literature about clinical practice.

The data analysis was conducted in four steps as recommended by the IPA strategies: (1) The authors read the data material first to become familiar with the content, individually providing 
comments and suggestions for themes for each case with a focus on the clients' meaning ${ }^{1}$. They met and discussed the possible themes that emerged from the first readings. (2) When re-reading the dataset afterward, they transformed the initial comments into preliminary interpretations across record transcripts and met to compare and discuss differences. When a theme overlapped other themes, it was omitted, and the quotations were reread to find another theme that could capture the meaning. The themes were repeatedly checked against the data, and accurate words were listed beside the themes to ensure their grounding in the empirical material. (3) When an agreement was obtained, all four authors read the themes with quotations from the data set once again and met to discuss the themes and interpretations. (4) When writing up the results, the first author selected one or more quotations as examples of the final themes and ensured the quotations corresponded with the whole case as a representation of the theme.

\section{Results}

In total, 67 written consents were sent or handed out to clients; 33 clients ( $66 \%$ female) responded positively and were included in this present study. All clients were aged between 18 and 65 years, with a mean age of 33 years and 16 clients below 30 years old. All participants had a Christian faith or Christian values or outlook.

How the clients described their faith experiences when asked in psychotherapy (research question 1) was divided into three overall themes (see Figure 1). The recurrences of the themes across cases (Smith et al. 2009, p. 107) can be seen in Table 1. Furthermore, all clients with a closing session in general described it as a strength that faith had been a part of their psychotherapy (see Table 1).

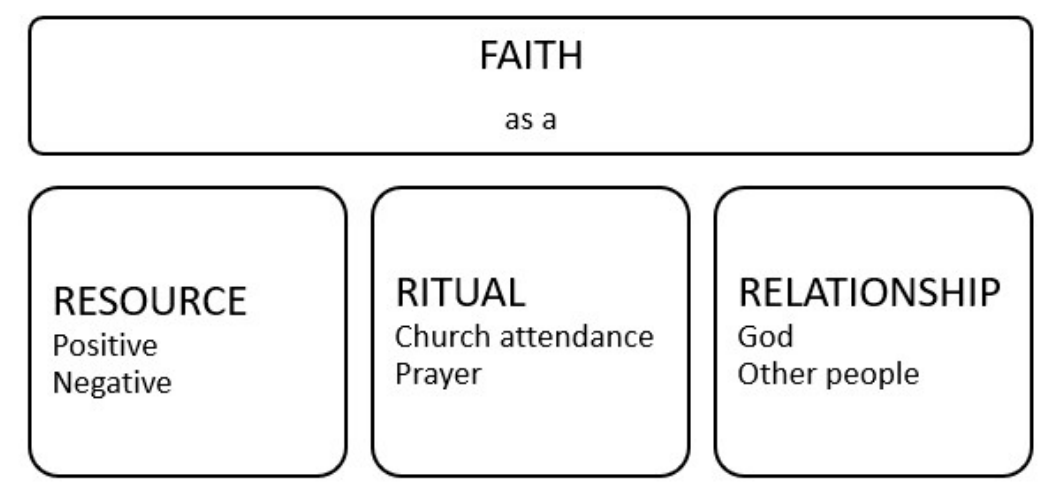

Figure 1. Three themes with subthemes regarding faith experiences.

1 A sample of 33 participants is in general considered to be too large for an interpretive phenomenological analysis (IPA) study. Nevertheless, due to the context of normal psychotherapy as a data source, the participants naturally differed in their richness of details described, which made the data useful for IPA. 
Table 1. Recurrences of the themes across cases.

\begin{tabular}{lccc}
\hline \multicolumn{1}{c}{ Themes } & $\begin{array}{c}\text { Strengths } \\
\text { (Clients/Quotes) }\end{array}$ & $\begin{array}{c}\text { Challenges } \\
\text { (Clients/Quotes) }\end{array}$ & $\begin{array}{c}\text { Is the Theme Present in } \\
\text { One-Third of the Sample? }\end{array}$ \\
\hline Faith as a resource & $25 / 43$ & $21 / 28$ & Yes \\
\hline $\begin{array}{l}\text { Relations } \\
\text { - to God }\end{array}$ & $19 / 43$ & $12 / 22$ & Yes (26 clients) \\
- to other people & $14 / 29$ & $8 / 16$ & \\
\hline $\begin{array}{l}\text { Rituals } \\
\text { prayer }\end{array}$ & $8 / 14$ & $6 / 6$ & Yes (20 clients) \\
- church attendance & $14 / 30$ & $10 / 16$ & \\
\hline $\begin{array}{l}\text { The psychological } \\
\text { implication of faith as a } \\
\text { strength or a challenge in }\end{array}$ & $8 / 21$ & $7 / 8$ & \\
$\begin{array}{l}\text { psychotherapy } \\
\text { (the psychologist's voice) }\end{array}$ & $9 / 9$ & $4 / 8$ & Yes (16/32 clients) \\
\hline $\begin{array}{l}\text { Evaluations of spirituality } \\
\text { and religiosity in } \\
\text { psychotherapy } \\
\text { (no evaluations }{ }^{3} \text { in eight of } \\
\text { the courses) }\end{array}$ & $16 / 30$ & $2 / 2$ & \\
\hline
\end{tabular}

To answer how the resources and challenges of the faith affected the client's psychological functioning (research question 2), the experiences of faith are first presented in this paper from the clients' view, followed by a presentation of the psychologists' view. Moreover, examples from our material will be given from the psychologists' view on how to use the knowledge about the clients' faith in clinical practice and psychotherapy (research question 3).

\subsection{Faith Experiences Described in Psychotherapy—Clients' View}

In our analysis of the material, the clients' descriptions of their faith experiences were divided into three themes: faith appraised as (1) a general resource in life, as (2) rituals, and as (3) relationships (Figure 1). These themes were described mainly as strengths that provided hope and meaning in life, but the same themes were also expressed as challenges or even as something that made life worse for the clients. For some, faith was experienced as an ambiguity and an equal experience of strength and challenge in relation to their faith. Our analysis indicates that faith could be experienced differently in terms of both intra- and interpersonal circumstances and had the possibility to change over time.

The themes with subthemes are presented as both a strength and a challenge and analyzed accordingly.

\subsubsection{Faith as a Resource}

\section{Positive resource}

In several cases, clients appraised their faith as something significant that provided them with meaning and hope, as seen in the following quotes:

Faith has carried me through hard times.

Faith is the foundation and it gives structure and meaning to my life.

2 The calculated numbers of clients are smaller than the total of strengths and challenges due to an overlap in cases where a client expressed the theme as both a strength and a challenge.

3 Due to missing the closing session $(n=6)$ or to spirituality or religiosity not being a part of therapy $(n=2)$. 
Faith also represented a basic strength and a resource through their changing life circumstances. In addition, faith represented a positive resource as a concrete coping strategy, as a male client said:

It's definitely important in my everyday life. It helps me at all levels (in life).

\section{Negative resource}

Although most clients described their faith as a positive resource ( 25 clients, see Table 1$), 21$ of the clients also experienced their faith as a challenge:

Faith can also be a challenge because when I'm going through a difficult patch, I also experience the most severe sense of doubt and find myself the furthest away from my faith.

It's a challenge to doubt, it gives me scruples.

I'm challenged by the Biblical talk of love and forgiveness. I cannot live up to the ideals due to my anger.

These are also examples of faith being experienced in general as an additional burden in times of crisis or as doubt rather than actual faith.

\subsubsection{Faith as a Ritual}

\section{Church attendance}

As a ritual, the clients in our study stated that church attendance strengthened their faith and was experienced as a positive emotional resource. The close connection between rituals and emotional needs was reflected in the statements of some of the clients:

Faith is a positive resource - receiving the communion is crucial to attending forgiveness.

Rituals in the church fulfilled psychological and emotional needs regarding being in good spirits and receiving forgiveness when they felt they had sinned. Nevertheless, the community also constituted a challenge when the clients were already distressed, as a woman stated:

I stay at home because I do not want the others to see me in a weak emotional state.

Church attendance as a ritual included seeing and being with other people. If there were vulnerabilities in these relationships, the use of the ritual could be decreased. In our material, it further became evident that illnesses, difficulties, or crises may lead to a decline in energy and thereby a decline in rituals that were used to promote meaning or energy in life. They constituted a possible challenge if clients were not able to use their previous ways to make meaning in life in times of crisis, as can be seen in the following example:

I have less energy for my usual religious activities-that's a challenge.

\section{Prayer}

Praying alone or in small groups served as a coping strategy in our material since it served as a ritualized way to practice one's faith, for some as morning or evening prayers, for others more in general:

I pray a lot, get my strength here, things find their place and I practice just to let it be.

Prayer is a part of the evening ritual and provides peace. An experience of laying something down and not being alone.

Moreover, the strength stemmed from the belief that there was a God who listened and took care. Although prayer could be a strength in times of crisis, it also caused frustrations, especially when the clients did not feel God was answering in the way they wished for, as was evident in the following two clients' experiences: 
I've tried to pray, cry, and call but it does not help. God is not answering.

It's difficult for me to believe. I prayed to God to heal my wife, now she is dead, and it's hard to live alone.

In several cases, as in the above examples, prayer functioned both as a ritual and as a relationship to God, thereby overlapping with "relationship to God" as a theme.

\subsubsection{Faith as a Relationship}

Relationships became evident in our analysis as an embedded part of practicing faith either in a relationship to God or to other people.

\section{Relationship to God}

Positive descriptions of clients' relationships with God were characterized as the importance that comes from knowing there is someone greater who looks after you, as well as the value of having someone to turn to with one's frustrations. A male client said:

It helps to know there is someone in control who wishes me well. There is a meaning in the madness.

A female client experienced God as a resource while going through a crisis that drained her energy:

I always have someone to turn to, someone to be angry with.

The relationship with God was also significant in some of the clients' explanations of faith as a positive resource in life, for example:

Faith means everything. God is a part of my everyday life. I share both my joys and my sorrows with God.

On the other hand, the relationship with God could also be filled with anger due to the feeling of distance, which was expressed as: "God is far away."

The following quote is an example of struggles in the relationship with God stemming from unfulfilled expectations of God:

My image of God is challenged by the illness and the difficult things in life.

Here, the client was challenged by her image of God as the helper that she had expected would give her what she most of all wanted and deeply prayed for. A different type of challenging God-image was explained by another client as stemming from her upbringing:

I have been challenged due to "the God of my childhood," who monitored my life and was this "big eye" watching me day and night.

As shown, both an actual and a former image of God can have a psychological impact on the clients' everyday life.

When evaluating psychotherapy in the last session, one client experienced being asked about faith as both a strength and a challenge, and the challenge was due to a:

bad conscience towards God and my Christian upbringing for not being motivated to talk about faith that day.

In this example, the client's actual feelings toward God impacted the experience of talking about God in psychotherapy. When faith is experienced as a relationship with God, it might be fruitful to assess it as a part of the client's relational system to be able to understand the client's lifeworld and intervene accordingly. The same client also evaluated the integration of faith in psychotherapy as: 
It was releasing for me that we talked about it because I realized that my feelings towards human relationships interfered with my view on my relationship with God.

\section{Relationships with other people}

When clients described their faith in relationships with other people, they mostly referred to the confidence they experienced in small groups, such as the gift of having a few people they prayed together with; for example, a male client stated:

I'm seeking comfort and conversations with fellow believers who contain and understand doubt.

The Christian fellowship and friends were described in more general terms as "a great and important, positive resource"; however, clients would also describe it as a challenge. The challenge was explained as being caused either by failures or disappointments in the relationships or by an experienced high demand to socialize:

All the time with distress, I have been challenged by the social situations in the church, for example, the coffee breaks.

\subsection{Faith Experiences Described in Psychotherapy—Psychologists' View}

From the clients' communication, as stated in the journals, it became evident that diverse ways of practicing faith were related to the psychological content of the psychotherapy. In the records, the psychologists had noted whether and how the spiritual or religious themes were a part of the interventions. In some of the records, the psychologist appraised that a change in the clients' perspective had taken place, as can be seen in the following example:

Guilty conscience and self-reproach in relation to reading the bible and praying also related to her basic feeling of not being good enough. Talking about new and more realistic actions helped her to be at peace with herself.

In the above example, the client reproached herself for not reading the Bible enough or praying too little, which was on a par with her basic, general feeling of not being good enough. In psychotherapy, the psychologist asked the client to explore and assess her expectations of herself based on her actual life circumstances and religious orientation. The client expressed the realization that different and more realistic expectations of herself regarding the amount of time spent on Bible reading and ways of praying were also compatible with her religious orientation. Facilitating the exploration of her general psychological feeling of not being good enough had a greater impact on her bad conscience more than her spiritual or religious orientation, which appeared as the psychotherapeutic work that helped the client to find new ways of practicing her faith and be at peace with her own religious choices.

In some cases, the religious content emerged as the main cause of distress, as the psychologist noted:

She sought me in relation to a spiritual dilemma, and I recommended her also to see a priest or read spiritual literature.

In this case, as a part of the psychological intervention, the client was referred to a chaplain or to read relevant literature to try to broaden her ideas and perspectives related to "the love of God."

(The client) described how cracks appeared in the old image of God and she was building up a new one. She explained that the new perspectives opened up and set her free. There seemed to be a cognitive restructuring process from expecting to understand God and get what she prays for to a containment of not being able to understand God.

The cross-disciplinary work between psychotherapy and the religious lectures in this case increased the client's flexibility in her faith practices and understandings, and the meaning for the client was evaluated afterward, as noted: 
She described how the sessions here and the teaching in the church have helped. She experienced that her faith changed in the process, becoming a more mature faith. She now seems to accept the difficult parts of life as normal and that life is not easy just because she is a Christian.

Differences between the psychologist and the client regarding health can arise, as seen in the following example:

In relation to the antidepressant medicine prescribed earlier, he (the client) had a spiritual experience of God saying to him that he could manage on his own. He described that it felt good. I validated the autonomy and his experience, but I also educated about the effect of the medicine and the fact that you still have to deal with your challenges yourself while taking medication. Next session: Talking about medicine again, he told me that in relation to God, asthma medicine was okay but medicine in relation to psychological challenges gave him the feeling of not being independent.

In the above example, the client's opinion about psychiatric medicine and personal independence is blurred with religious experiences, making it unclear whether one of the arguments weighed heavier than the other. Another example of diversities between the psychologist and the client regarding health is where a psychologist wrote:

She experienced that God told her which job to choose and she would not go against God's will. When I explored about this experience, she radiated a flexible approach like, "I must try, and I can always quit if it's not the right job for me".

The first expression externalized the client's responsibility (indicating God as responsible), and when the psychologist inquired further, a more flexible version was noticed. The client's answer showed an internalized responsibility (indicating her responsibility) that allowed the client to change if the job was not the right one for her. Externalizing her responsibility was accompanied by a passive attitude that seemed to only be a part of the client's lifeworld, whereas another part was a more flexible and active attitude toward her own life.

The implications for psychotherapeutic practice, as stated in the result section, will be discussed and related to extended, theoretical literature, which is also in line with our IPA approach.

\section{Discussion}

This present study investigated the need for assessing clients' faith experiences as part of psychotherapy. Faith seemed to be intertwined with the client's psychosocial life and posed both a resource and a challenge toward coping with therapy-related problems. Our clients appreciated that the therapist assessed, and in some instances, integrated the client's faith directly into the therapy.

The analysis conveyed three themes, faith as a resource, as a ritual, and as a relationship, where all of them emerged as a strength, a challenge, or as uncertainty in between. The themes also exemplified the clients' different coping strategies when seeking an overall meaning system, ritualized behavior, and social support in times of distress. If the client's faith practices were impaired, a psychological inquiry of the possible causes and connections to the client's life story could help to determine what was significant for the client and how new possible practices could be tested. Consequently, psychotherapy might benefit from assessing and intervening according to the client's faith experiences and concerns, as was evident in the therapeutic relationship and practice. The clinical implications for faith as themes in psychotherapy are discussed below with the use of selected, extended literature on psychological functioning and religiosity.

\subsection{When the "Sacred" Is a Part of Psychotherapy}

In our material, clients expressed that faith (besides being a resource) was also a challenge. For many, it was frustrating, and for some, it was also surprising when faith was not experienced as a strength in times of crisis. For the client to reveal vulnerable experiences demands a great deal 
of trust and a relationship between the psychologist and the client such that the client feels safe (Jørgensen 2018). Furthermore, when something is significant in life, people treat it with special care and respect, and accordingly, perceptions of violations or loss of what is significant or perhaps "sacred" can elicit stronger emotional and behavioral reactions (Pargament et al. 2017). When psychologists ask about faith and religiosity in psychotherapy, a spiritual or religious client might be alert to the psychologist's possible interpretation of their faith to protect what they hold as significant and sacred. This requires that the therapist holds a sensitive and open approach regarding the client's culture and beliefs and discloses a willingness to learn about the value of faith in the client's life (Pargament 2007; Gonsiorek et al. 2009; Barnett and Johnson 2011). Overall, the clients evaluated addressing faith in psychotherapy as a strength of the treatment approach. This might be understood as a consequence of their faith as encompassing a significant resource in their life and therefore important for them to integrate into their therapy if relevant.

\subsection{Religious Struggles Related to Religious Orientation}

Anger toward God is one of the most researched types of religious struggles. It has been found to result in poorer health behavior and wellbeing (Exline 2013; Barnett and Johnson 2011; Stauner et al. 2016). Taking the clients' history of religious struggles in psychotherapy as a part of the assessment might therefore be helpful for the therapeutic relationship and the intervention (Pargament 2007).

In our material, we saw how a female client's image of a loving and protecting God was challenged by her current situation and illness. This image might be difficult to maintain when the client experiences life in all its complexity, thereby generating frustration and anger toward God, which causes experiences of faith to be a challenge. The image of God and the way people use their faith can be interpreted as consequences of the individual's religious orientation. Allport described two religious orientations (Allport and Ross 1967): The extrinsic orientation defines religiosity as an instrumental device that is used to provide security, sociability, status, or comfort, which is opposed to the intrinsic orientation, where religion is considered a value in its own right. The intrinsic orientation has often been connected to positive qualities and health, in contrast to the extrinsic orientation, which among other factors, relates positively to narcissism as a personality disorder (Koenig et al. 2012). Although Allport's approach has been critically discussed (Kirkpatrick and Hood 1990; Masters 1991), his focus on the function of religion and the individual orientation has inspired further empirical and theoretical developments (Tønnesvang 2006). One example is Pargament's development of three styles of coping. One of these coping styles is called a "deferred coping approach" (Pargament 2007, p. 163), which characterizes the externalization of responsibility to God, which is tied to lower self-esteem, poorer problem-solving skills, and Allport's extrinsic orientation (Pargament et al. 1988). Most often, religious people combine both intrinsic and extrinsic orientations when living their faith (Pargament 2007). A recent study points to "religious individualism," which is characterized as a "lived expectation of having one's specific individual needs met through one's religiosity" (Viftrup et al. 2017, p. 123). Although the participants described a personal integration of their faith, they also used their faith as an instrumental device, i.e., an expectation was integrated into their religiosity of faith as a means to obtain individual security and comfort (Viftrup et al. 2017). In the present study, several clients mentioned that prayer and the relationship with God were challenged when they did not receive the answers they wished for, such as healing for a loved one. This could be explained as a merely extrinsic orientation, but due to the clients' experiences of faith as also being a significant resource in itself, it is more equivalent to "religious individualism" as an expectation of the fulfilment of individual needs. Still, since their faith is used as an instrumental device, there may be a risk for the same negative correlations to lower self-esteem and poorer problem-solving skills, as in the deferred coping approach.

If faith is understood as a way to obtain security, comfort, and the fulfilment of individual needs, religious struggles, such as disappointment in God, are more likely to occur as life evolves in all its complexity. In our analyses, we also saw clients with an unequivocal image of God struggling with this when they experienced difficult things in life. "Spiritual struggles" are well-known in the 
international literature and are found to be negatively related to health (Abu-Raiya et al. 2015; Ano and Vasconcelles 2005; Exline 2013). It is therefore relevant to explore the clients' individual experiences and understandings about spiritual struggles and sensitively discuss with the client whether faith is understood as a means to obtain comfort or whether there are conflicting experiences of faith as both a significant resource and a challenge. In our analysis, this was evident in the case where the client explained her image of God and faith as changing from a means to obtain what she wished for toward a more flexible faith that also contained uncertainty and the acceptance of not being able to understand God. Interventions regarding these religious struggles can be positively related to health because it can help the client resolve a possible conflict, for example, by finding a broader and more nuanced image of God, as illustrated in our material.

\subsection{The Human Being As a Social Being}

Relationships are an integrated and inevitable part of human life: the social part is "always already installed in the individual" (Katzenelson 1994, p. 19), and therefore part of the content of psychotherapy, for example, how the individual challenges are expressed in relationships with family, friends, or colleagues (Watzlawick et al. 1967). Moreover, according to perspectives from developmental psychology, human beings depend on relationships to develop, and development is more likely to occur in relationships with an openness for meeting moments (Stern 2004; Stern et al. 1998). A meeting moment is a present moment of authenticity and a unique, individual contribution to the relationship. Meeting moments resemble the intense presence characterizing the I-Thou relationship, which in the philosophy of Martin Buber (Buber 1997) is viewed as a precondition for actually being an I, and accordingly, the concept of meeting moments has been suggested as an important part of changes in psychotherapy (Andersen 2020; Viftrup et al. 2020; Stern 2004; Stern et al. 1998). The relational significance in relation to changes in psychotherapy is also developed in the concept of sacred moments (Pargament et al. 2017; Lomax et al. 2011). Sacred moments are defined as moments experienced with spiritual qualities of transcendence, ultimacy, boundlessness, interconnectedness, and spiritual emotions (Pargament et al. 2017; Lomax et al. 2011), where the interconnectedness is characterized as the Buberian I-Thou meeting. In relation to psychotherapy, sacred moments cover both the conversation about moments with sacred qualities in the client's life (as in faith experiences) and important moments in the therapeutic relationship as meeting moments. Sacred moments are found to have a powerful impact on the client's life, such as heightened satisfaction and finding meaning in life (Lomax et al. 2011). As the human being is fundamentally a social and relational being, moments with the I-Thou quality that encompasses emotions related to what the client holds sacred seems to be important to address and be open to in psychotherapy.

Relationships with fellow believers can constitute an example of how an individual experiences the resources or challenges in their social environment, such as in our present study, where relationships were used as a resource to obtain comfort and social support, especially in times of distress. However, for some, relationships also became a challenge due to the experience of excessive demands to socialize. This might be important to integrate into psychotherapy, especially if the faith is experienced as significant because relationships to fellow believers are thus likely to be important for the client's social life per se.

From a theoretical and relational perspective on human life, faith cannot be lived out solely on an individual level but is always lived out in relationships with other beings or with a form of transcendence, such as God (Buber 1997). This corresponds to our analysis showing that faith is experienced in relationships, both to fellow believers and to God, and constitutes a theoretical and empirical argument for recognizing the relevance of the theme faith as a relationship in psychotherapy, both as a resource and as a challenge. 


\subsection{Religious Coping}

In some of our cases, the clients expressed a guilty conscience about taking part in too little church attendance and prayer. In psychotherapy, new possible ways to pray and be together with fellow believers were explored and tried out at home, which gave a new, positive confidence in their faith practices. Pargament (2007) has introduced four pathways that people use to seek what they experience as significant or sacred in life: emotional experience, knowledge, community, and behavior, including rituals. When applied in the psychotherapeutic context, the more methods a person can use to obtain contact with what is significant in life, the better. Having more opportunities to assess one's possible resources in life is likely to reduce vulnerability. When a ritual behavior, such as church attendance, is challenged because of the inherent, possible social situations, the client will be more vulnerable if the ritual is the only way to relate to the sacred and less vulnerable if there are other ways to attend to what is significant in life. Addressing diverse ways to relate to faith can be a valuable approach in psychotherapy for a spiritually and religiously oriented client to obtain a more flexible and resource-oriented faith and practice.

As shown in our analysis, prayer represents an important coping strategy for many, and thus, can be a part of intervention during psychotherapy as soothing behavior. However, it may be clinically important to explore the meaning for the client in the current situation of distress and not to take the ritual's positive influence for granted (Pargament 2007). An exploration of other behavioral strategies or ways to manage was shown to be helpful for some of the clients when the ritual became a challenge.

\subsection{Faith Experiences as Opportunities and Challenges for Psychotherapy}

Our findings indicate that faith experiences were integrated into the clients' psychological functioning, and accordingly, they were valuable to know about and include as part of the psychotherapy when relevant. To these clients, faith was not a rigid part of life but changed as their lives changed, thereby faith could also change as a part of their psychotherapy. In several cases, the clients' faith practices or their relationship with God were explicit themes in the psychotherapy, and the psychological approach was helpful for the clients, either as a validation of the positive resources in faith or as a broadening of the perspectives toward a more flexible faith.

However, when a client expresses beliefs or practices in faith that a therapist assesses to be psychologically unhealthy, it might challenge the therapist or the alliance. A possible solution for the psychologist is to focus on whether and how the client's belief could relate to negative health outcomes and assess and discuss this with the client with an open mind (Slattery and Park 2012). In our findings, we had an example of a client with an experience of God saying to him that he could manage without the prescribed medicine. By assessing the possible discrepancies between the client's situational beliefs ("God has told me not to get help from psychiatric medicine") and the global beliefs ("God is not against medicine and health-related treatment in general"), the psychologist can further facilitate a possible broadening of the client's perspectives (Slattery and Park 2012). In another case, the client at first showed an inflexible faith practice through externalizing the responsibility for the choice of their job onto God. When the psychologist explored the choice further, the client expressed an internalized responsibility too by saying that she could always quit if the job was not right for her.

Focusing on the psychological function for the client and ethical standards and legal codes (Gebler and Maercker 2014) can guide the psychologist when dilemmas arise between the clients' faith experiences and the therapists' health-related experiences. Still, a potential value conflict exists when the client holds spiritual beliefs that contradict the psychologist's values and goals, not personally, but as a healthcare professional, as illustrated in the case where the client was dismissive of medicine for faith-related reasons. Besides using supervision and education as psychologists to guide own professional attitude and treatment approach, an ethical rule of thumb is to have the client in focus and the clients' rights to decide what is true and important according to their spiritual or religious orientation. This is also on par with the treatment approach defined as client- and patient-centeredness (Thompson 2007; Gonsiorek et al. 2009), which is characterized by a cooperating relationship with shared decisions. 
In this approach, the psychologist would share with the client the relevant professional knowledge and discuss the implications for treatment and choices with continual respect for the client's autonomy and right to decide. In the abovementioned case, where a client dismissed medicine for faith-related reasons, the psychologist could find a way through the ethical dilemma by sharing healthcare knowledge, while openly discussing the possible implications for treatment with respect for the clients' autonomy, vulnerabilities, and competencies to decide what is subjectively right (Gulbrandsen et al. 2016).

In the present study, the clients' expressions cover three well-known domains in psychology: cognitive-behavioral (the appraisal of something as significant and the practice of rituals), social (the relationships to fellow believers or the transcendence), and personality (individual religious orientations). Consequently, the psychologist can draw on this general psychological knowledge in psychotherapy with spiritually or religiously oriented clients. Studies have indicated that a therapist's own worldview is associated with the responses given in a clinical situation (Peteet et al. 2016; Curlin et al. 2005). Therefore, psychologists might also need training in and education on how to address faith experiences and how to intervene in psychological practice to assure an approach that is based not on their values, worldview, or faith experiences, but rather on psychological knowledge and experience.

From the psychological profession and discipline, a judgement of the faith's true value cannot be made, but a judgement of the function the faith has for the client can be made. Through a referral to religious guides and sources, new perspectives can be introduced in a religious language, including a possible ontological confirmation, such as the true value of the metaphysical world, which is beyond the authority of the psychologist (Gonsiorek et al. 2009; Slattery and Park 2012; American Psychological Association 2007). A combination of psychotherapy and religious guidance appeared in our analyses as an important part of the treatment process for one of the clients. Therefore, a referral to a religious guide (e.g., a chaplain) can be important to consider when the psychological mandate ends.

\subsection{Methodological Considerations}

A strength of this study is that the statements and stories were collected in a therapeutic context. The recording was done after each session, thereby avoiding the memory confounder that often occurs when clients or therapists talk about the whole therapy retrospectively (Kvale and Brinkmann 2014). Moreover, journals should be written with the client in focus. The psychologists had treated the clients for a period and knew the contexts in which these themes occurred when they extracted these issues from the journals. A possible bias in the data collection was that the data were reflected through the psychologists' memory and notes from therapy, and the treating psychologists themselves extracted the relevant data from the journals. Another bias was that the validity of the knowledge, drawn from the analysis of the journals, depended on the character of the therapeutic relationship, including the degree of confidence each client had in their therapist. The degree of confidence affected how disposed the client was to disclose personal issues, such as faith experiences. A way to deal with these biases is to conduct a study where clients are interviewed after each session about their perspectives on the treatment and compare their experiences with the psychologists' journals. However, an approach where clients are interviewed immediately after each therapy session will comprise ethical and treatment-related challenges due to the nature and process of psychotherapeutic treatment (Jørgensen 2018).

Another possible limitation is the use of a methodological approach to analyze therapy records that is normally used and recommended for interview data, although diaries are also recommended as data material in the interpretative phenomenological analysis (IPA) framework. On the other hand, the commitment in the IPA approach to invite participants to give a rich, detailed first-person perspective of their experiences and take them seriously with attention to the contextual factors (Smith et al. 2009) suits the approach taken to produce the therapy records. Moreover, a theoretical analysis of the journals based on the concept of "sacred moments" in psychotherapy could be addressed in a further study as a potential important ingredient in the therapeutic alliance. 
The first author worked as a psychologist in the clinical practice, and as such, was very close to the data. To overcome the possible researcher bias, the second and third authors were primarily involved in analyzing the data, and the first author discussed the risk of bias with all the authors several times throughout the study.

\section{Conclusions}

Faith experiences can represent a significant part of human life as strengths and challenges, or in a negative version, produce a risk to health. This paper suggests that psychologists ask about clients' faith experiences to assess the importance and possible connections with the client's psychosocial life. When faith functions as a possible source of meaning in a client's life, it can be an important theme to integrate into the psychotherapeutic context such that the psychologist and client can explore these issues and intervene according to the strengths and challenges of the client's faith experiences and the resulting impact on the client's health. Otherwise, psychologists risk losing knowledge that can be a significant part of the psychological healing and wellbeing of the client.

This study was carried out in a clinical context with an overrepresentation of clients with a Christian religious faith or value-based background. Studying a diversity of religions and faith experiences in relation to the clinical implications and dilemmas for psychotherapy hereof would be valuable. Furthermore, there is a need for research to deepen how psychologists approach faith experiences in psychotherapy in a more secular context.

Author Contributions: A.H.A. and H.F.P. conceived and designed the project. A.H.A., H.F.P. and D.T.V. conducted the initial analyses with K.K.R. as a supervisor. A.H.A. wrote the manuscript, and all authors have contributed to the design, analysis, and have read and commented on the manuscript. All authors have read and agreed to the published version of the manuscript.

Funding: This research received no external funding.

Acknowledgments: We are grateful to the clients for sharing their valuable experiences, and we thank the psychologists, the institution "Agape," and the proofreader for their worthwhile contributions to this study.

Conflicts of Interest: The authors declare no conflict of interest.

\section{References}

Abu-Raiya, Hisham, Julie J. Exline, Kenneth I. Pargament, and Qutaiba Agbaria. 2015. Prevalence, Predictors, and Implications of Religious/Spiritual Struggles Among Muslims. Journal for the Scientific Study of Religion 54: 631-48. [CrossRef]

Abu-Raiya, Hisham, Kenneth I. Pargament, and Neal Krause. 2016. Religion as problem, religion as solution: Religious buffers of the links between religious/spiritual struggles and well-being/mental health. Quality of Life Research 25: 1265-74. [CrossRef] [PubMed]

Allport, Gordon W., and J. Michael Ross. 1967. Personal religious orientation and prejudice. Journal of Personality and Social Psychology 5: 432-43. [CrossRef] [PubMed]

American Psychological Association. 2007. Resolution on Religious, Religion-Based and/or Religion-Derived Prejudice. American Psychologist 63: 431-34.

Andersen, Aida Hougaard. 2020. Physicians' Communication about Existential, Spiritual and Religious Needs with Patients Living with Chronic Pain or Multiple Sclerosis: Conversation or Nonversation? Ph.D. Dissertation, University of Southern Denmark, Faulty of Health, Odense, Denmark.

Andersen, Aida Hougaard, Elisabeth Assing Hvidt, Niels Christian Hvidt, and Kirsten Kaya Roessler. 2019. Doctor-patient communication about existential, spiritual and religious needs in chronic pain: A systematic review. Archive for the Psychology of Religion 23. [CrossRef]

Andersen, Aida Hougaard, Elisabeth Assing Hvidt, Niels Christian Hvidt, and Kirsten Kaya Roessler. 2020. 'Maybe we are losing sight of the human dimension'—physicians' approaches to existential, spiritual, and religious needs among patients with chronic pain or multiple sclerosis. A qualitative interview-study. Health Psychology and Behavioral Medicine 8: 248-269. [CrossRef] 
Ano, Gene G., and Erin B. Vasconcelles. 2005. Religious coping and psychological adjustment to stress: A meta-analysis. Journal of Clinical Psychology 61: 461-80. [CrossRef]

APA. 2013. APA Handbook of Psychology, Religion, and Spirituality: V.1: Context, Theory, and Research; V.2: An Applied Psychology of Religion and Spirituality. Washington, DC: American Psychological Association.

Assing Hvidt, Elisabeth, Jens Søndergaard, Jette Ammentorp, Lars Bjerrum, Dorte Gilså Hansen, Frede Olesen, Susanne S. Pedersen, Helle Timm, Connie Timmermann, and Niels Christian Hvidt. 2016. The existential dimension in general practice: Identifying understandings and experiences of general practitioners in Denmark. Scandinavian Journal of Primary Health Care 34: 385-93. [CrossRef]

Aten, Jamie, Kari O'Grady, and Everett Worthington Jr. 2012. The Psychology of Religion and Spirituality for Clinicians. Using Research in Your Practice. New York: Routledge.

Ausker, Nadja, Peter la Cour, Christian Busch, Henning Nabe-Nielsen, and Lotte Mørk Pedersen. 2008. Existential thoughts and religious life of Danish patients. Ugeskrift for Laeger 170: 1828-33.

Austad, Arne, and Gry Stålsett Follesø. 2003. Religiøse og eksistentielle erfaringer i psykoterapi [Religious and Existential Issues in Psychotherapy]. Tidsskrift for Norsk Psykologforening 40: 8.

Balint, Enid. 1969. The possibilities of patient-centered medicine. Journal of the Royal College of General Practitioners 17: 269-76.

Barnett, Jeffrey E., and W. Brad Johnson. 2011. Integrating Spirituality and Religion Into Psychotherapy: Persistent Dilemmas, Ethical Issues, and a Proposed Decision-Making Process. Ethics E Behavior 21: 147-64. [CrossRef]

Best, Megan, Phyllis Butow, and Ian Olver. 2016. Doctors discussing religion and spirituality: A systematic literature review. Palliative Medicine 30: 327-37. [CrossRef] [PubMed]

Buber, Martin. 1997. Jeg og Du [Ich und Du], 3rd ed. Denmark: Hans Reitzel. First published 1923.

Curlin, Farr A., John D. Lantos, Chad J. Roach, Sarah A. Sellergren, and Marshall H. Chin. 2005. Religious characteristics of US physicians: A national survey. Journal of General Internal Medicine 20: 629-34. [CrossRef] [PubMed]

Delaney, Harold D., William R. Miller, and Ana M. Bisonó. 2007. Religiosity and spirituality among psychologists: A survey of clinician members of the American Psychological Association. Professional Psychology: Research and Practice 38: 538-46. [CrossRef]

Dezutter, Jessie, Martin Offenbaecher, Miguel A. Vallejo, Siebrecht Vanhooren, Evalyne Thauvoye, and Loren Toussaint. 2016. Chronic pain care: The importance of a biopsychosocial-existential approach. International Journal of Psychiatry in Medicine 51: 563-75. [CrossRef] [PubMed]

Dyer, Allen R. 2011. The need for a new "new medical model": A bio-psychosocial-spiritual model. Southern Medical Journal 104: 297-98. [CrossRef] [PubMed]

Engel, George L. 1977. The need for a new medical model: A challenge for biomedicine. Science 196: 129-36. [CrossRef]

Exline, Julie J. 2013. Religious and spiritual struggles. In APA Handbook of Psychology, Religion, and Spirituality (Vol 1): Context, Theory, and Research. Washington, DC: American Psychological Association, pp. 459-75.

Fitchett, George, Patricia E. Murphy, Jo Kim, James L. Gibbons, Jacqueline R. Cameron, and Judy A. Davis. 2004. Religious Struggle: Prevalence, Correlates and Mental Health Risks in Diabetic, Congestive Heart Failure, and Oncology Patients. International Journal of Psychiatry in Medicine 34: 179-96. [CrossRef]

Freud, Sigmund. 1989. The Future of an Illusion (Die Zukunft Einer Illusion). New York: W. W. Norton \& Company. First published 1927.

Fromm, Erich. 1983. Psychoanalysis and Religion (/Psykoanalyse og Religion). New Haven: Yale University Press (Copenhagen, Hans Reitzels Forlag). First published 1950.

Gebler, Florian A., and Andreas Maercker. 2014. Effects of including an existential perspective in a cognitive-behavioral group program for chronic pain: A clinical trial with 6 months follow-up. The Humanistic Psychologist 42: 155-71. [CrossRef]

Gonsiorek, John C., P. Scott Richards, Kenneth I. Pargament, and Mark R. McMinn. 2009. Ethical challenges and opportunities at the edge: Incorporating spirituality and religion into psychotherapy. Professional Psychology: Research and Practice 40: 385-95. [CrossRef] 
Gulbrandsen, Pål, Marla L. Clayman, Mary Catherine Beach, Paul K. Han, Emily F. Boss, Eirik H. Ofstad, and Glyn Elwyn. 2016. Shared decision-making as an existential journey: Aiming for restored autonomous capacity. Patient Education and Counseling 99: 1505-10. [CrossRef] [PubMed]

Hofmann, Liane, and Harald Walach. 2011. Spirituality and religiosity in psychotherapy-A representative survey among German psychotherapists. Psychotherapy Research 21: 179-92. [CrossRef]

Hvidt, Niels Christian, Dorte Hvidtjørn, Kaare Christensen, Jesper Bo Nielsen, and Jens Søndergaard. 2017. Faith moves mountains-mountains move faith: Two opposite epidemiological forces in research on religion and health. Journal of Religion and Health 56: 294-304. [CrossRef] [PubMed]

Jørgensen, Carsten René. 2018. Den Psykoterapeutiske Holdning (The Psychotherapeutic Approach). Copenhagen: Hans Reitzel.

Katzenelson, Boje. 1994. Homo Socius. Socialpsykologisk Grundbog. [Social Psychology Introduction]. Copenhagen: Gyldendal.

Kirkpatrick, Lee A., and Ralph W. Hood Jr. 1990. Intrinsic-Extrinsic Religious Orientation: The Boon or Bane of Contemporary Psychology of Religion? Journal for the Scientific Study of Religion 29: 442-62. [CrossRef]

Koenig, Harold, Harold George Koenig, Dana King, and Verna B. Carson. 2012. Handbook of Religion and Health, 2nd ed. Oxford: Oxford University Press, p. 1169 s.

Koenig, Harold G., Faten Al-Zaben, and Tyler J. VanderWeele. 2020. Religion and psychiatry: Recent developments in research. BJPsych Advances, 1-11. [CrossRef]

Kvale, Steinar, and Svend Brinkmann. 2014. Interview. Det kvaliatative forskningsinterview Som Håndværk (Interview. Qualitative Research Interview as a Craft), 3rd ed. Copenhagen: Hans Reitzels Forlag.

La Cour, Peter. 2008. Existential and religious issues when admitted to hospital in a secular society: Patterns of change. Mental Health, Religion \& Culture 11: 769-82. [CrossRef]

Larsen, Janni Lisander, Elisabeth OC Hall, Søren Jacobsen, and Regner Birkelund. 2017. Being in a standstill-of-life: Women's experience of being diagnosed with systemic lupus erythematosus: A hermeneutic-phenomenological study. Scandinavian Journal of Caring Sciences 32: 654-62. [CrossRef]

Lazarus, Richard S. and Susan Folkman. 1984. Stress, Appraisal, and Coping. New York and Berlin: Springer.

Lomax, James W., Jeffrey J. Kripal, and Kenneth I. Pargament. 2011. Perspectives on "Sacred Moments" in Psychotherapy. American Journal of Psychiatry 168: 12-18. [CrossRef]

Masters, Kevin S. 1991. Of Boons, Banes, Babies, and Bath Water: A Reply to the Kirkpatrick and Hood Discussion of Intrinsic-Extrinsic Religious Orientation. Journal for the Scientific Study of Religion 30: 312-17. [CrossRef]

Moestrup, Lene, and Niels Christian Hvidt. 2016. Where is God in my dying? A qualitative investigation of faith reflections among hospice patients in a secularized society. Death Studies 40: 618-29. [CrossRef]

Mueller, Paul S., David J. Plevak, and Teresa A. Rummans. 2001. Religious involvement, spirituality, and medicine: Implications for clinical practice. Mayo Clinic Proceedings 76: 1225-35. [CrossRef]

Pargament, Kenneth I. 1997. The Psychology of Religion and Coping. Theory, Research, Practice. New York: The Guilford Press.

Pargament, Kenneth I. 2007. Spiritually Integrated Psychotherapy: Understanding and Addressing The Sacred. New York: Guilford Press, pp. xvi, 384 s.

Pargament, Kenneth I., Joseph Kennell, William Hathaway, Nancy Grevengoed, Jon Newman, and Wendy Jones. 1988. Religion and the Problem-Solving Process: Three Styles of Coping. Journal for the Scientific Study of Religion 27: 90-104. [CrossRef]

Pargament, Kenneth I., Melissa D. Falb, Gene G. Ano, and Amy B. Wachholtz. 2013. The religious dimension of coping: Advances in theory, research, and practice. In Handbook of the Psychology of Religion and Spirituality, 2nd ed. Edited by Raymond F. Paloutzian and Crystal L. Park. New York: The Guilford Press.

Pargament, Kenneth I., Doug Oman, Julie Pomerleau, and Annette Mahoney. 2017. Some contributions of a psychological approach to the study of the sacred. Religion 47: 718-44. [CrossRef]

Pedersen, Heidi F., Kenneth I. Pargament, Christina G. Pedersen, and Robert Zachariae. 2013. Religious coping and quality of life among severely ill lung patients in a secular society. International Journal for the Psychology of Religion 23: 188-203. [CrossRef]

Pedersen, Heidi Frølund, Marit Handegard Birkeland, Jens Søndergaard Jensen, Tatjana Schnell, Niels Christian Hvidt, Torgeir Sørensen, and Peter La Cour. 2018. What brings meaning to life in a highly secular society? A study on sources of meaning among Danes. Scandinavian Journal of Psychology 59: 678-90. [CrossRef] [PubMed] 
Peteet, John R., Vithya B. Rodriguez, Marta D. Herschkopf, Alyssa McCarthy, Jennifer Betts, Stephanie Romo, and J. Michael Murphy. 2016. Does a Therapist's World View Matter? Journal of Religion and Health 55: 1097-106. [CrossRef] [PubMed]

Reme, Silje Endresen. 2014. Psykologiprofesjonens forhold til religion [The Relationship between Psychologists and Religion]. In Religionspsykologi [Psychology of Religion]. Edited by Lars Johan Danbolt, Leif Gunnar Engedal, Hans Stifoss-Hanssen, Knut Hestad and Lars Lien. Oslo: Gyldendal Akademisk.

Rizzuto, Ana-Marie. 1979. The Birth of the Living God. Chicago: Universitu of Chicago Press.

Schnell, Tatjana. 2011. Individual differences in meaning-making: Considering the variety of sources of meaning, their density and diversity. Personality and Individual Differences 51: 667-73. [CrossRef]

Slattery, Jeanne M., and Crystal L. Park. 2012. Religious and Spiritual Beliefs in Psychotherapy. A Meaning Perspective. In The Psychology of Religion and Spirituality for Clinicians. Using Research in Your Practice. Edited by Jamie Aten, Kari O'Grady and Everett Worthington Jr. New York: Routledge.

Smith, David P., and David E. Orlinsky. 2004. Religious and Spiritual Experience Among Psychotherapists. Psychotherapy: Theory, Research, Practice, Training 41: 144-51. [CrossRef]

Smith, Jonathan A., Paul Flowers, and Michael Larkin. 2009. Interpretative Phenomenological Analysis: Theory, Method and Research. London: Sage.

Stålsett, Gry, Tore Gude, M. Helge Rønnestad, and Jon T. Monsen. 2012. Existential dynamic therapy ("VITA") for treatment-resistant depression with Cluster C disorder: Matched comparison to treatment as usual. Psychotherapy Research 22: 579-91. [CrossRef]

Stauner, Nick, Julie J. Exline, and Kenneth I. Pargament. 2016. Religious and Spiritual Struggles as Concerns for Health and Well-Being/Lutas religiosas e espirituais relativas à saude e ao bem-estar. Horizonte 14: 48-75. [CrossRef]

Stern, Daniel N. 2004. De første Seks Måneder [The First Relationship: Infant and Mother]. Copenhagen: Hans Reitzels Forlag.

Stern, Daniel N., Louis W. Sander, Jeremy P. Nahum, Alexandra M. Harrison, Karlen Lyons-Ruth Alec, C. Morgan Nadia Bruschweiler-Stern, and Edward Z. Tronick. 1998. Non-interpretive mechanisms in psychoanalytic therapy: The 'something more' than interpretation. The International Journal of Psycho-Analysis 79: 903-21.

Stewart, William C., Michelle P. Adams, Jeanette A. Stewart, and Lindsay A. Nelson. 2013. Review of clinical medicine and religious practice. Journal of Religion and Health 52: 91-106. [CrossRef]

Sulmasy, Daniel P. 2002. A biopsychosocial-spiritual model for the care of patients at the end of life. Gerontologist 42: 24-33. [CrossRef] [PubMed]

Thompson, Andrew G.H. 2007. The meaning of patient involvement and participation in health care consultations: A taxonomy. Social Science \& Medicine 64: 1297-310. [CrossRef]

Tomcsányi, Teodóra, Viola Sallay, Zsuzsanna Jáki, Péter Török, Tünde Szabó, András Ittzés, Krisztina Csáky-Pallavicini, Edith A. Kiri, Katalin Horváth-Szabó, and Tamás Martos. 2017. Spirituality in Psychotherapy: An Analysis of Hungarian Psychoterapists' Experiences-A Grounded Theory Study. Archive for the Psychology of Religion 39: 235-62. [CrossRef]

Tønnesvang, Jan. 2006. Elementer i religiøsitetens psykologik [Elements of the psychology of religiosity]. In Religiøsitet Og Selopsykologi [Religiosity and Self Psychology]. Edited by Jan Tønnesvang and Preben Bertelsen. Århus: Klim.

Van der Heyden, Karen, Jessie Dezutter, and Wim Beyers. 2015. Meaning in Life and depressive symptoms: A person-oriented approach in residential and community-dwelling older adults. Aging $\mathcal{E}$ Mental Health 19: 1063-70. [CrossRef]

Viftrup, Dorte Toudal, Peter La Cour, Niels Buus, and Niels Christian Hvidt. 2016. Religious Transformation Among Danish Pentecostals Following Personal Crisis and Group Psychotherapy: A Qualitative Study. Journal of Spirituality in Mental Health 18: 1-23. [CrossRef]

Viftrup, Dorte Toudal, Niels Christian Hvidt, and Niels Buus. 2017. Religious Coping in a Christian Minority Group: A Qualitative Study among Pentecostal Danes. Nordic Journal of Religion and Society 30: 115-35. [CrossRef] 
Viftrup, Dorte Toudal, S. Wong, Kenneth I. Pargament, Aida Hougaard Andersen, and Niels Christian Hvidt. 2020. Sacred Moments in Religiously Integrated Group Therapy for Danish Pentecostals-An IPA Analysis. Submitted.

Watzlawick, Paul, Janet Beavin Bavelas, and Don D. Jackson. 1967. Pragmatics of Human Communication. A Study of Interactional Patterns, Pathologies, and Paradoxes. New York: W. W. Norton \& Company.

(C) 2020 by the authors. Licensee MDPI, Basel, Switzerland. This article is an open access article distributed under the terms and conditions of the Creative Commons Attribution (CC BY) license (http://creativecommons.org/licenses/by/4.0/). 